\title{
Visokošolsko izobraževanje - njegov pomen in financiranje v Sloveniji
}

UDK: 378.014.543(045)

\author{
Maja Klun \\ Univerza v Ljubljani, Fakuleta za upravo \\ maja.klun@fu.uni-lj.si
}

Marina Šućur

Univerza v Ljubljani

marina.sucur@uni-lj.si

\section{IZVLEČEK}

Izobrazba postaja problematična predvsem glede zadostnosti sredstev, saj javno financiranje ne zadostuje več. Članek obravnava problematiko financiranja visokošolskega izobraževanja $z$ vidika zadostnosti sredstev in $z$ vidika pomena izobraževanja. Prikazani so načini neposrednega in posrednega financiranja izobraževanja v Sloveniji in rezultati raziskave, $v$ kateri so študenti navedli svoje mnenje o pomenu izobraževanja in financiranju. Velika večina anketirancev se strinja, da bi uvedba šolnin povzročila manjšo udeležbo populacije $v$ visokem šolstvu ter da bi se tako zmanjšale enake možnosti izobraževanja. Kljub temu pa se največji delež anketirancev ni strinjal s trditvijo, da se v primeru plačila šolnin ne bi šolali.

Ključne besede: visokošolsko izobraževanje, financiranje, pomen študija, Slovenija.

JEL: A23, H52

\section{Uvod}

Izobrazba že od nekdaj velja za pomembno družbeno vrednoto. Pridobiva se na visokošolskih ustanovah, ki so danes dostopnejše širšemu krogu ljudi, kot so bile nekoč, zato število študentov narašča. Posledično postaja problematična zadostnost sredstev, javno financiranje ne zadostuje več, zato strokovnjaki poleg javnega na tem področju čedalje bolj zagovarjajo zasebno financiranje 
Maja Klun, Marina Šućur

Visokošolsko izobraževanje -

njegov pomen in financiranje $v$ Sloveniji

izobraževanja $\vee$ obliki šolnin, posojil ipd. Zasebno financiranje izobraževanja vsekakor pripomore $k$ zadostnosti sredstev, vendar je vprašljivo zagotavljanje enakih možnosti izobraževanja. Poleg tega je razlog za javno financiranje tudi ta, da izobraževanje ne prinaša koristi le posamezniku, temveč posredno celotni družbi. Za gospodarsko rast in uspešen razvoj potrebuje država izobražene ljudi. Interes posameznika pa se nanaša na pričakovanja o bodoči zaposlitvi in dohodku, kakovosti življenja, osebnostnem razvoju ipd.

Visoko šolstvo se torej danes sooča predvsem z naslednjimi problemi: $v$ večini držav upadajo finančna sredstva univerz, saj so financirane iz davkov, pojavljajo se skrbi glede njihove kakovosti, nezadostna je pomoč študentom, delež študentov iz nižjih socialnih slojev je majhen, posledično je večina prejemnikov ugodnosti iz premožnejših družin.

Za evropske države je veljalo, da so visokošolske ustanove tradicionalno pretežno javno financirane. Čeprav so si strokovnjaki enotni, da je treba povečati udeležbo posameznikov pri financiranju, se večina javnosti še vedno ne strinja s tem. Omejitve so predvsem psihične in socialne narave, saj je vedno veljalo, da mora biti izobraževanje brezplačno ter enako dostopno vsem socialnim slojem. Pravica do brezplačnega študija pa je po večini zagotovljena z ustavo ali zakonom. Nekatere raziskave kažejo (Aghion et al., 2010), da zunanje financiranje visokošolskih institucij vodi $\vee$ njihovo večjo produktivnost, če so institucije bolj avtonomne in soočene z večjo konkurenco. Glede na raziskave Del Rey in Racionero (2010) je kreditiranje glede na dohodkovne kontingente in s skupnim tveganjem najbolj optimalen način participacije študenta, ki istočasno upošteva stroške izobraževanja in izgubljeni dohodek v času študija.

$\checkmark$ članku so predstavljeni načini in oblike javnega financiranja visokošolskega izobraževanja, in sicer tako ustanov kot študentov prek neposrednih ali posrednih oblik financiranja. Sledi predstavitev porabljenih finančnih sredstev za izobraževanje in primerjava s članicami EU. Zadnji del članka prikazuje rezultate obsežne raziskave med študenti o njihovem videnju pomena visokošolskega izobraževanja in financiranja.

\section{Pomen visokošolskega izobraževanja in njegovo financiranje}

Izobraževanje mnogi uvrščajo med mešane (oz. kvazi javne) dobrine, ki so zasebne $v$ porabi, oskrba z njimi pa je $v$ javnem interesu (javno financiranje in/ali 
Maja Klun, Marina Šućur

Visokošolsko izobraževanje njegov pomen in financiranje v Sloveniji

javna oskrba). Visokošolska izobrazba torej prinaša koristi tako posamezniku kot širši okolici (stranske koristi ali eksternalije). Glavni problem je merjenje dejanskega obsega koristi. Ni jih mogoče izmeriti po enotni lestvici, če jih je sploh mogoče izmeriti (Vossensteyn, 2004, str. 40). Bevc et al. (2001, str. 13) menijo, da gre pri visokem izobraževanju za vprašanje, ali je masovno visokošolsko izobraževanje primarno individualna ali primarno družbena dobrina, oz. ali imajo od tega izobraževanja večjo korist družba ali šolajoči. Dokler je število vključenih $v$ to izobraževanje majhno, z vidika izdatkov to ni pomembno vprašanje, kasneje pa je treba naraščanje državnih izdatkov upravičiti ali z vidika pravičnosti ali učinkovitosti. Ocenjuje se, da čim večje je število oseb, ki imajo koristi od visokega izobraževanja (imajo visoko izobrazbo), tem večja je relativna neenakopravnost tistih, ki nimajo visoke izobrazbe. Za visoko šolstvo (redni študij) lahko zato rečemo, da je javna dobrina $\vee$ tistem obsegu, ki ga je država pripravljena in sposobna financirati.

Po navadi povpraševanje po visokošolskem izobraževanju narašča $\vee$ obdobju gospodarske krize. Posamezniki, ki ostanejo brezposelni ali imajo malo možnosti za zaposlitev, vidijo visokošolsko izobrazbo kot način do boljših zaposlitvenih možnosti. Vendar pa veliko število diplomantov vpliva na rast ponudbe delovne sile z visoko izobrazbo, kar posledično pomeni tudi nižjo ceno te delovne sile. Pri tem se pojavlja vprašanje, ali sploh še lahko govorimo o koristih, ki naj bi jih imel posameznik od višje izobrazbe. Leta 2008 so se grški študenti v demonstracijah proti izobraževalnemu sistemu v državi poimenovali 'Generacija 700 evrov', saj kljub višji izobrazbi ne dobijo boljše plačanih zaposlitev.

Javno financiranje visokošolskega izobraževanja ima tako več plati. Težja zaposljivost visokošolskih diplomantov namreč pomeni pritisk tudi na socialne izdatke in ne prinaša več le koristi. Glede na letno poročilo Zavoda RS za zaposlovanje stopnja izobrazbe, ki je $v$ preteklosti igrala veliko vlogo pri zaposlitvenih možnostih, danes večinoma ni več tako pomembna (Zavod RS za zaposlovanje, 2009). Največjo skupino brezposelnih oseb so še vedno osebe z najnižjo stopnjo izobrazbe, ki jih je bilo v letu 2009 v povprečju 39,4 \%. Brezposelnih s šesto in sedmo stopnjo izobrazbe ali več je bilo v letu $200910 \%$, vendar delež te skupine narašča v zadnjih letih bolj kot pri drugih skupinah. 
Maja Klun, Marina Šućur

Visokošolsko izobraževanje -

njegov pomen in financiranje $v$ Sloveniji

\section{Neposredno in posredno financiranje viso- košolskega izobraževanja v sloveniji}

Za sistem financiranja visokega šolstva $v$ Sloveniji je značilno, da je financirano pretežno iz javnih sredstev. Državna sredstva prejemajo tako izobraževalne ustanove kot študenti. Prav tako so prejemniki državnih sredstev za izobraževanje zasebne visokošolske ustanove, ki imajo dodeljeno koncesijo za izvajanje javne službe.

Način financiranja visokega šolstva $v$ Sloveniji ureja Zakon o visokem šolstvu (ZViS), in sicer $\vee$ 8. poglavju (72.-78. člen). Po zakonu se sredstva za dejavnost visokošolskih ustanov določajo $v$ državnem proračunu ob upoštevanju študijskega področja ter števila vpisanih študentov in diplomantov rednega študija prve in druge stopnje. Zakon predvideva podrobnejšo ureditev financiranja s posebnim predpisom, ki ga sprejme Vlada Republike Slovenije. Financiranje visokošolskih ustanov je torej podrobneje urejeno z Uredbo o javnem financiranju visokošolskih in drugih zavodov, članic univerz, od leta 2004 do leta 2008. $\vee$ tem obdobju je bila Uredba štirikrat spremenjena in dopolnjena, nazadnje oktobra 2008, ko je bila sprejeta Uredba o spremembah in dopolnitvah Uredbe o javnem financiranju visokošolskih in drugih zavodov, članic univerz, od leta 2004 do leta 2008, s katero je bila podaljšana veljavnost sedanjega načina financiranja še za leto 2009. Za naslednje obdobje od leta 2010 naprej je $\checkmark$ pripravi nova uredba, vendar bi za stabilnost financiranja tega področja bilo bolje, če bi le-to bilo urejeno z zakonom (kot to predvideva tudi Ustava RS).

$\checkmark$ Sloveniji obstaja neposredna državna finančna pomoč študentom le $v$ obliki štipendij, ki so omejene na nadarjene (Zoisova štipendija) in tiste, ki izhajajo iz družin z nižjim dohodkom na družinskega člana (državna štipendija). V novem Zakonu o štipendiranju je predvideno sofinanciranje kadrovskih štipendij z namenom povečanja števila le-teh. Sistem državno podprtih študentskih posojil je nerazvit, študenti lahko najamejo študentska posojila pri bankah, vendar pa so le-ta nenamenska (namen porabe ni znan).

Štipendije ureja Zakon o štipendiranju (Zštip, Ur. I. RS, št. 59/2007). V njem so štipendije opredeljene kot dopolnilni prejemek, namenjen za kritje stroškov $\vee$ zvezi z izobraževanjem (5. člen ZŠtip). V 9. členu Zštip so določeni splošni pogoji za pridobitev štipendije: "Štipendijo po tem zakonu lahko pridobijo upravičenci, ki ob prvem vpisu $\vee$ prvi letnik višješolskega ali visokošolskega izobraževanja oziroma ob prvem vpisu na prvo, drugo ali tretjo stopnjo izobraževanja niso starejši od 26 let, in: 
Maja Klun, Marina Šućur

Visokošolsko izobraževanje njegov pomen in financiranje v Sloveniji

- hkrati ne prejemajo katere od štipendij iz 5. člena tega zakona,

- ne prejemajo štipendije ali drugih prejemkov za izobraževanje po drugih predpisih,

- niso $v$ delovnem razmerju oziroma ne opravljajo samostojne registrirane dejavnosti,

- niso vpisani $v$ evidenco brezposelnih oseb pri Zavodu Republike Slovenije za zaposlovanje (v nadaljnjem besedilu: zavod). «

13. člen Zštip je bil spremenjen z Zakonom o spremembah in dopolnitvah Zakona o štipendiranju (Zštip-A, Ur. I. RS, št. 40/2009). Določa, da se državne štipendije dodelijo kandidatom, ki izpolnjujejo splošne pogoje iz tega zakona in pri katerih povprečni mesečni dohodek na družinskega člana $\vee$ preteklem koledarskem letu pred vložitvijo vloge ne presega $65 \%$ (pred spremembo je ta meja znašala $60 \%$ ) minimalne plače na družinskega člana $v$ istem obdobju za tiste kandidate, ki se šolajo ali študirajo $v$ kraju svojega stalnega bivališča, in od $66 \%$ do 68 \% (pred spremembo je bila meja od $60 \%$ do $65 \%$ ) minimalne plače na družinskega člana za tiste kandidate, ki se šolajo ali študirajo izven kraja svojega stalnega bivališča.

Zoisovo štipendijo po 24. členu Zštip lahko pridobi dijak ali študent, ki izpolnjuje splošne pogoje in:

- ima v višješolskem ali visokošolskem izobraževanju povprečno oceno najmanj 8,5 ali več, ali

- je glede na povprečno oceno uvrščen med najboljših $5 \%$ študentov $v$ svoji generaciji, ali

- je dosegel izjemne dosežke na posameznem področju družbenega življenja ne glede na letnik šolanja.

Kot je že omenjeno, država namenja finančna sredstva tudi za posredno pomoč študentom. Subvencioniranje prehrane je bilo normativno urejeno šele leta 1996 s prvim upravno-pravnim aktom na tem področju, in sicer z Uredbo o subvencioniranju študentske prehrane (Ur. I. RS, št. 24/1996). Leta 2002 pa je bil sprejet tudi Zakon o subvencioniranju študentske prehrane (ZSšP, Ur. I. RS, 85/2002). Po ZSšP (6. člen) so upravičenci do subvencionirane študentske prehrane "vsi, ki imajo status študenta in niso zaposleni«. Za razliko od štipendij so tu upravičenci vsi, ne glede na socialni položaj. Pravilnik o subvencioniranju študentske prehrane (Ur. I. RS, št. 70/2007) pa natančneje opredeljuje upravičence, in 
Maja Klun, Marina Šućur

Visokošolsko izobraževanje -

njegov pomen in financiranje $v$ Sloveniji

sicer so to tako redni kot tudi izredni študentje, ki niso zaposleni ali prijavljeni na Zavodu Republike Slovenije za zaposlovanje kot iskalci zaposlitve. Subvencioniranje prehrane se izvaja $v$ obliki bonov za kosilo. Posameznik je upravičen do enega subvencioniranega obroka za vsak delovni dan, razen za čas šolskih počitnic (od 10. julija do 20. avgusta).

Subvencioniranje bivanja študentov je predpisano $\vee$ ZViS. $\vee$ njem so navedena merila, ki se upoštevajo pri izbiri: študijska uspešnost, materialni položaj, oddaljenost stalnega bivališča od kraja študija ter socialne in zdravstvene razmere študenta. Podrobnejše določbe so urejene $\vee$ Pravilniku o subvencioniranju bivanja študentov (Ur. I. RS, št. 22/2001). Ureja tudi točkovanje omenjenih meril za izbiro. Subvencija znaša najmanj 20 \% povprečne mesečne cene bivanja. Subvencijo lahko študenti uveljavljajo tudi za bivanje pri zasebnikih. Pravilnik določa minimalni standard, ki ga morajo študentski domovi in zasebniki zagotavljati študentu. Cena bivanja v študentskih domovih in pri zasebnikih se zmanjša za toliko, kolikor znaša subvencija.

Subvencioniranje prevoza prav tako predpisuje že ZViS. Do subvencije so upravičeni študenti, ki se izobražujejo v oddaljenosti $5 \mathrm{~km}$ ali več od kraja stalnega bivališča. Določena je minimalna subvencija, in sicer $v$ višini 7 odstotkov od cene mesečne vozovnice. Višina subvencije je odvisna od socialnega položaja in oddaljenosti od kraja izobraževanja. Subvencije so podrobneje urejene v Pravilniku o subvencioniranju prevozov študentov (Ur. I. RS, št. 18/2004). Pravilnik razvršča višino subvencije $v$ štiri razrede glede na bruto mesečni dohodek na družinskega člana $v$ odstotku od bruto povprečne plače na zaposlenega $\vee$ RS. Višina subvencije se $\vee$ vsakem razredu zviša za $10 \%$ za oddaljenost nad $40 \mathrm{~km}$ in do $60 \mathrm{~km}$ od stalnega prebivališča študenta od kraja izobraževanja in za 20 \% za oddaljenost nad $60 \mathrm{~km}$. Stroški prevoza pa so lahko dodatno pokriti v okviru štipendij. Mestni potniški promet pa subvencionira občina.

Zdravstveno varstvo (zavarovanje) študentov ureja Zakon o zdravstvenem varstvu in zdravstvenem zavarovanju (ZZVZZ-UPB3, Ur. I. RS, št. 72/2006). Na njegovi podlagi imajo študenti pravico do vseh zdravstvenih storitev do konca rednega šolanja (22. člen). Zakon o spremembah in dopolnitvah Zakona o zdravstvenem varstvu in zdravstvenem zavarovanju (ZZVZZ-K, Ur. I. RS, št. 76/2008) je omejil upravičence do zdravstvenega zavarovanja na šolajoče do dopolnjenega 26. leta starosti. Davčne olajšave za šolajoče in njihove starše določa Zakon o dohodnini (ZDoh-2, Ur. I. RS, št. 117/2006). Splošna olajšava se prizna rezidentu pod pogojem, da zanj nihče drug ne uveljavlja posebne olajšave za vzdrževanega družinskega člana (111. člen ZDoh-2). To pomeni, da 


\section{Maja Klun, Marina Šućur \\ Visokošolsko izobraževanje - njegov pomen in financiranje $v$ Sloveniji}

so do splošne olajšave upravičeni tisti študenti, ki jih starši niso uveljavljali kot vzdrževane člane. Posebno olajšavo torej lahko izkoristijo starši, ki vzdržujejo šolajoče družinske člane, njena velikost pa je odvisna tudi od števila vzdrževanih članov in je določena v 114. členu ZDoh-2. 3. odstavek 113. člena ZDoh-2 določa posebno osebno olajšavo rezidentu, ki se izobražuje (ima status dijaka ali študenta, vendar do dopolnjenega 26. leta starosti) in začasno ali občasno dela na podlagi napotnice pooblaščene organizacije. Zneski olajšav se enkrat letno uskladijo s koeficientom rasti cen življenjskih potrebščin $\vee$ Sloveniji za mesec november tekočega leta $v$ primerjavi $z$ mesecem novembrom prejšnjega leta po podatkih Statističnega urada Republike Slovenije (118. člen ZDoh-2). Študentu se v olajšavo šteje še 10 odstotkov normiranih stroškov od dohodka preko napotnic, ki jih ni potrebno posebej dokazovati.

Starši šolajočih so prav tako upravičeni do otroškega dodatka, ki je dopolnilni prejemek za preživljanje, vzgojo in izobraževanje otroka, kadar dohodek na družinskega člana ne presega $99 \%$ povprečne plače $\vee$ Republiki Sloveniji $\vee$ preteklem koledarskem letu. Pravica do otroškega dodatka je opredeljena $\vee$ Zakonu o starševskem varstvu in družinskih prejemkih (ZSDP-UPB2, Ur. I. RS, št. 110/2006) v 57. členu. Pravico lahko starši uveljavljajo do dopolnjenega 18. leta otroka oz. do dopolnjenega 26. leta starosti (izjemoma tudi po dopolnjenem 26. letu starosti), če ima status dijaka ali študenta.

\section{Javni izdatki za visokošolsko izobraževanje}

V Sloveniji so stroški rednega študija $\vee$ celoti financirani iz javnih sredstev, saj izobraževalne ustanove prejemajo državna sredstva za izvajanje programov rednega dodiplomskega študija oz. 1. in 2. bolonjske stopnje (plačilo šolnin za redni študij prepoveduje ZViS). Izredni študij pa je financiran iz zasebnih virov (prispevek šolajočih in njihovih staršev oz. delodajalcev), in sicer s plačilom šolnin v višini celotnih stroškov poučevanja na študenta.

Javni izdatki države in občin, namenjeni za formalno izobraževanje $v$ Sloveniji, so v letu 2007 znašali 1.795 milijonov EUR ali 5,21 \% BDP, od tega $1,21 \%$ za terciarno izobraževanje, skupaj je to pomenilo slabo petino (18\%) vseh javnih izdatkov za izobraževanje. Država je nekaj manj kot $28 \%$ vseh sredstev za formalno izobraževanje namenila za terciarno izobraževanje, občine pa le dobre $3 \%$ za srednješolsko in terciarno izobraževanje skupaj (SURS, 2009). 
Maja Klun, Marina Šućur

Visokošolsko izobraževanje -

njegov pomen in financiranje $v$ Sloveniji

Proračunska sredstva države in občin za formalno izobraževanje, ki so bila namenjena izobraževalnim ustanovam, pomenijo $92 \%$ teh sredstev, medtem ko se za transferje gospodinjstvom in za druge zasebne entitete porablja $8 \%$. Od navedenih 92\% sredstev za izobraževalne ustanove se le slabih $20 \%$ (ali 323 milijonov EUR) namenja za terciarno izobraževanje, njihov delež in višina pa sta se zmanjšala. Po drugi strani pa so bili skoraj vsi javni transferji namenjeni za terciarno izobraževanje, in sicer okoli dve tretjini. V sestavi vseh javnih izdatkov za terciarno izobraževanje v letu 2007 so tako transferji za gospodinjstva in druge zasebne entitete bili slaba četrtina skupnih javnih izdatkov (SURS, 2009).

Kot je že navedeno, država s subvencijami gospodinjstvom sodeluje pri kritju življenjskih stroškov študentov. Gospodarstvo prispeva h kritju življenjskih stroškov $\vee$ okviru kadrovskih štipendij, vendar število le-teh pomeni majhen delež $\vee$ celotnem sistemu štipendiranja (dobra desetina vseh podeljenih štipendij). Po podatkih SURS za leto 2007 število vseh štipendistov (dijakov in študentov) upada, le še dobra četrtina prejema štipendijo, tako da največje breme življenjskih stroškov nosijo študenti in njihovi starši (vendar je delež teh stroškov zaradi različnih okoliščin in potreb posameznikov težko merljiv).

$\checkmark$ državah članicah EU imajo šolnino $v 16$ državah, vpisnino pa $\vee 13$. Znotraj EU se kaže trend $k$ zaračunavanju šolnine za redni študij $v$ javnih ustanovah. Nekatere države so šolnino vpeljale $\vee$ zadnjih letih, $\vee$ nekaterih pa o njeni vpeljavi razpravljajo. Šolnino za redni študij večinoma določi država in se $v$ EU giblje med 200 in 1.000 EUR. V EU je vpisnina večinoma nižja od 200 EUR. Za daljši študij od uradno določenega študenti plačajo $v 15$ državah EU, v 9 med njimi študenti plačajo le v tem primeru (Eurostat, 2007; v Bevc, 2008, str. 9). Publikacija Eurostata o ključnih kazalnikih visokega izobraževanja v Evropi navaja kot edini primer nasprotnega trenda Slovenijo. Po deležu javnih izdatkov za izobraževanje v BDP za leto 2006 je bila Slovenija uvrščena na osmo mesto po deležu javnih izdatkov za terciarno izobraževanje $\vee$ BDP med vsemi državami članicami EU. Delež sredstev namenjenih za terciarno izobraževanje $\vee$ državah EU je prikazan $\checkmark$ tabeli 1 na naslednji strani.

Delež državnih subvencij študentom, gospodinjstvom in drugim zasebnim entitetam je $v$ državah OECD v letu 2005 v povprečju znašal 18 odstotkov celotnih javnih izdatkov za visokošolsko izobraževanje (manj kot v letu 2007 v Sloveniji). Močno nad povprečjem držav OECD pa sta bili Norveška in Nova Zelandija, katerih delež subvencij $\vee$ celotnih javnih izdatkih za visokošolsko izobraževanje je znašal več kot 40 odstotkov v letu 2005 (Highlights from Education at a Glance, 2008, str. 60). V primerjavi s povprečjem v državah OECD je 
Maja Klun, Marina Šućur

Visokošolsko izobraževanje njegov pomen in financiranje v Sloveniji

delež zasebnih izdatkov v Sloveniji nekoliko nižji. V državah OECD se kaže trend upadanja deleža javnih izdatkov za visokošolske izobraževalne ustanove, delež zasebnih izdatkov se je v letih od 1995 do 2005 povečal za 6 odstotkov in je v navedenem letu znašal 27 odstotkov skupnih izdatkov za visokošolske ustanove (Highlights from Education at a Glance, 2008, str. 58).

Tabela 1: Delež javnih izdatkov za terciarno izobraževanje v \% BDP

\begin{tabular}{|c|c|c|c|}
\hline \multirow[t]{2}{*}{ država } & \multicolumn{3}{|c|}{ leto } \\
\hline & 2004 & 2005 & 2006 \\
\hline EU- 27 & 1.13 & 1.15 & 1.13 \\
\hline Belgija & 1.29 & 1.29 & 1.32 \\
\hline Bolgarija & 0.80 & 0.76 & 0.73 \\
\hline Češka & 0.94 & 0.89 & 1.23 \\
\hline Danska & 2.51 & 2.38 & 2.27 \\
\hline Nemčija & 1.16 & 1.14 & 1.11 \\
\hline Estonija & 0.86 & 0.93 & 0.92 \\
\hline Irska & 1.10 & 1.11 & 1.14 \\
\hline Grčija & 1.32 & 1.44 & - \\
\hline Španija & 0.97 & 0.95 & 0.95 \\
\hline Francija & 1.21 & 1.19 & 1.19 \\
\hline Italija & 0.77 & 0.76 & 0.80 \\
\hline Ciper & 1.48 & 1.58 & 1.65 \\
\hline Latvija & 0.68 & 0.88 & 0.91 \\
\hline Litva & 1.06 & 1.03 & 1.00 \\
\hline Luksemburg & - & - & - \\
\hline Madžarska & 1.02 & 1.03 & 1.04 \\
\hline Malta & 0.53 & 1.06 & - \\
\hline Nizozemska & 1.45 & 1.47 & 1.50 \\
\hline Avstrija & 1.44 & 1.49 & 1.48 \\
\hline Poljska & 1.15 & 1.19 & 0.96 \\
\hline Portugalska & 0.83 & 0.98 & 1.00 \\
\hline Romunija & 0.70 & 0.81 & - \\
\hline Slovenija & 1.31 & 1.25 & 1.24 \\
\hline Slovaška & 0.98 & 0.81 & 0.90 \\
\hline Finska & 2.07 & 2.01 & 1.94 \\
\hline Švedska & 2.04 & 1.92 & 1.84 \\
\hline Združeno Kraljestvo & 1.00 & 1.20 & 1.10 \\
\hline
\end{tabular}


Maja Klun, Marina Šućur

Visokošolsko izobraževanje -

njegov pomen in financiranje $v$ Sloveniji

\section{Izvedba raziskave}

\subsection{Potek raziskave in vzorec}

$\checkmark$ raziskavi smo ocenili pomen visokošolskega izobraževanja in njegovega financiranja. Vprašanja in trditve so bila oblikovana na podlagi teoretičnih ugotovitev in mnenj strokovnjakov s tega področja. Anketa je bila pripravljena s pomočjo spletne strani www.surveymonkey.com. Povezava na anketo je bila objavljena na študentskih forumih. Izpolnjevanje ankete je potekalo $v$ obdobju od 28. 5. 2009 do 30. 06. 2009. Ankete ni bilo mogoče zaključiti, ne da bi bili podani odgovori na vsa vprašanja, tako so $v$ analizi upoštevane le $v$ celoti izpolnjene ankete. Pri posameznem vprašanju je bilo mogoče obkrožiti le en odgovor. Skupaj je bilo anketiranih 400 študentov različnih slovenskih univerz in samostojnih visokošolskih zavodov.

Anketa je bila sestavljena iz dveh delov. Prvi del je vseboval splošne podatke o anketirancih. $V$ drugem delu so anketiranci odgovorili na vprašanja o visokošolskem izobraževanju in njegovem financiranju ter ovrednotili 16 trditev na lestvici od 1 do 4, pri čemer so ocene imele naslednji pomen: 1 - sploh se ne strinjam, 2 - se ne strinjam, 3 - strinjam se, 4 - popolnoma se strinjam. Lestvica je bila oblikovana s sodim številom možnosti zato, da se vsakdo opredeli, oz. da ni sredinskega odgovora, ko je nekomu vseeno.

Anketni vprašalnik je izpolnilo 62 odstotkov žensk in 38 odstotkov moških. Med vsemi vprašanimi je bilo največ starih 23 in 24 let, in sicer je pri obeh starostih delež znašal 16 odstotkov. Velika večina anketiranih študira na dodiplomski ali prvi stopnji (95 odstotkov), le 5 odstotkov pa študira na podiplomski ali drugi stopnji. Večina anketiranih je vpisanih na redni študij (80 odstotkov), drugi študirajo izredno. Med vsemi največji delež predstavljajo absolventi, in sicer 35 odstotkov. Glede strukture vzorca lahko trdimo, da ta ne odstopa bistveno od strukture $v$ celotni populaciji. Po podatkih Statističnega urada RS za leto 2008 je bilo $v$ visokošolski študij vpisanih 59,7 \% žensk, delež izrednih študentov je bil $27,4 \%$, delež absolventov je znašal 19,3 \%, v dodiplomski študij oziroma na prvo stopnjo študija pa je bilo vpisanih $88,2 \%$ študentov.

\subsection{Analiza rezultatov raziskave}

$\checkmark$ nadaljevanju so prikazani rezultati raziskave, $s$ katerimi je ocenjeno mnenje anketiranih študentov glede namena študija in ocena mnenja o financiranju. V Grafu 
Maja Klun, Marina Šućur

Visokošolsko izobraževanje njegov pomen in financiranje v Sloveniji

1 so prikazani odgovori študentov na vprašanje o razlogih, zakaj se izobražujejo na visokošolski ravni. Največ študentov (32 odstotkov) meni, da lahko z visokošolsko izobrazbo dobijo boljšo zaposlitev, nekaj odstotkov manj (29 odstotkov) je mnenja, da imajo po končanem študiju več možnosti pri iskanju zaposlitve. Zaradi želje po znanju pa se izobražuje 27 odstotkov vprašanih. Nihče ni navedel neuspešnega iskanja zaposlitve kot razlog za nadaljevanje šolanja na visokošolski ravni.

\section{Graf 1: Razlogi za šolanje}

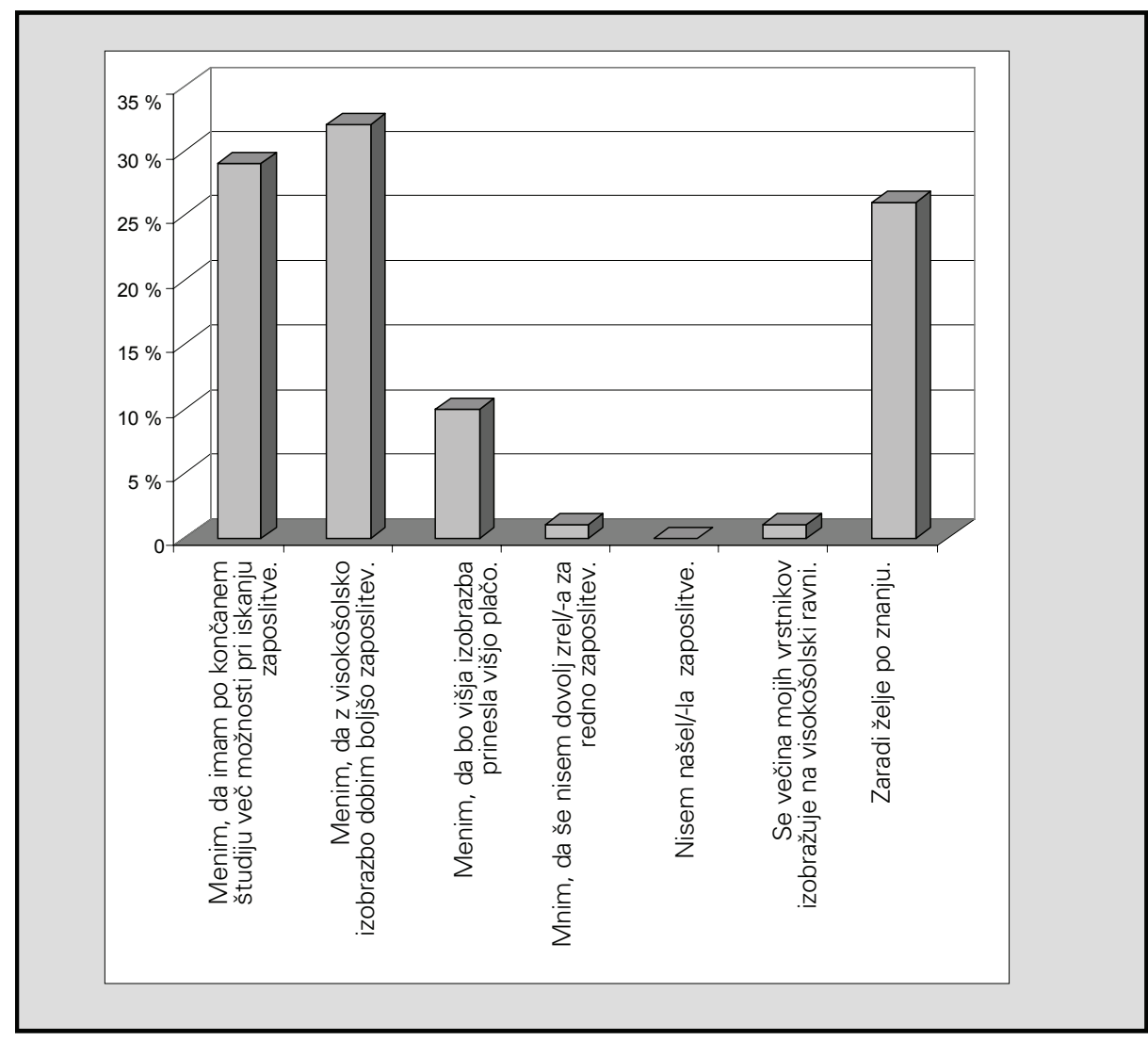

Vir: Anketa.

Glede financiranja visokoolske izobrazbe je bila večina anketiranih (68 odstotkov) mnenja, da je visokošolsko izobraževanje javna dobrina in zato mora biti brezplačno. 30 odstotkov anketiranih je menilo, da imata koristi od visokošolske izobrazbe tako družba kot posameznik, zato bi si stroške izobraževanja morala deliti. Le 2 odstotka anketiranih pa je bilo mnenja, da ima od 
Maja Klun, Marina Šućur

Visokošolsko izobraževanje -

njegov pomen in financiranje $v$ Sloveniji

visokošolske izobrazbe koristi predvsem posameznik in bi stroške visokošolskega izobraževanja moral kriti sam.

$\checkmark$ Tabeli 2 je navedenih 16 trditev in povprečna ocena strinjanja anketiranih z njimi. Kot že rečeno, je bila ocenjevalna lestvica od 1 do 4 , tako so tudi povprečne ocene $v$ tem razponu. Za trditev, ki je bila ocenjena $s$ povprečno oceno manj kot 2,5 velja, da se večina vprašanih ni strinjala z njo. $S$ trditvami, ki so bile ocenjene s povprečno oceno več kot 2,5 , pa se je večina vprašanih strinjala. Za trditve, ki so se najbolj približale povprečni oceni 2,5, velja, da so si bili anketiranci najmanj enotni. Anketirani študentje so se najbolj strinjali s trditvijo, da bi državno podprta posojila morala vsebovati spodbude za študente. Prav tako je bil velik delež anketiranih študentov mnenja, da bi se z uvedbo šolnin zmanjšale enake možnosti izobraževanja in bi uvedba šolnin povzročila manjšo udeležbo populacije $v$ visokem šolstvu.

Najmanj pa so se strinjali s trditvijo, da se $v$ primeru plačila šolnine ne bi šolali, češ da višja stopnja izobrazbe ne vpliva na višino plače. Torej lahko sklenemo, da bi bili pripravljeni investirati $v$ izobrazbo, saj od nje pričakujejo denarne koristi v prihodnosti. Prav tako so bili mnenja, da kljub temu da je študij brezplačen in velik delež populacije študira in študij tudi zaključi, izobrazba vseeno pomeni boljše možnosti pri iskanju zaposlitve. Večina se tudi ni strinjala $s$ trditvijo, da bi v primeru šolnin visokošolske ustanove bolj skrbele za kakovost in učinkovitost izvajanja programov.

Glede možnosti odplačevanja šolnin preko študentskih posojil so si bili anketiranci najmanj enotni. Polovica anketiranih se ni strinjala z navedeno trditvijo, druga polovica pa se $\vee$ primeru plačila šolnine za študij ne bi odločila zaradi strahu pred prihodnjim dolgom. Mnenje anketirancev je bilo deljeno tudi glede trditve, da bi se $v$ primeru šolnin vpisovali le tisti, ki imajo resen namen študirati. Prav tako si niso bili enotni glede morebitnega diskriminatornega zaračunavanja šolnin za izredne študente.

Glede na spol se odgovori niso veliko razlikovali in tudi niso odstopali od skupnega povprečja. Kot glavni razlog za šolanje so moški izrazili željo po znanju. Predvsem moški so bili mnenja, da imajo od visokošolske izobrazbe koristi posamezniki in bi si zato morali stroške kriti sami. Glede na vrsto študija je prihajalo do večjih razlik in odstopanj od povprečja predvsem pri podiplomskih študentih. Polovica vprašanih podiplomskih študentov (50 odstotkov) je kot razlog za šolanje navedla željo po znanju. Kar 64 odstotkov je bilo mnenja, da bi si družba in posameznik morala stroške izobraževanja deliti. Tudi zelo velik delež podiplomskih študentov (82 odstotkov) namerava študij dokončati v pred- 
Maja Klun, Marina Šućur

Visokošolsko izobraževanje njegov pomen in financiranje v Sloveniji

videnem času trajanja. Precej odstopanj od skupnega povprečja je bilo tudi pri povprečnih ocenah strinjanja s trditvami, ni pa prišlo do nasprotujočih mnenj.

Tabela 2: Povprečna ocena strinjanja vprašanih s trditvami

\begin{tabular}{|c|c|}
\hline & $\begin{array}{l}\text { povprečna } \\
\text { ocena }\end{array}$ \\
\hline $\begin{array}{l}\text { Država ni sposobna financirati povečane vključenosti prebivalstva } v \text { viso- } \\
\text { košolskem izobraževanju na tradicionalen način (iz javnih sredstev). }\end{array}$ & 2.42 \\
\hline $\begin{array}{l}\text { Država bi morala nameniti več sredstev za neposredne oblike pomoči (štipendi- } \\
\text { je, študentska posojila) kot za posredne (subvencije za prehrano, prevoz, bivan- } \\
\text { je ...). }\end{array}$ & 3.01 \\
\hline $\begin{array}{l}\text { Plačilo šolnin za izredni študij je } v \text { primerjavi z brezplačnim rednim študijem } \\
\text { diskriminatorno. }\end{array}$ & 2.46 \\
\hline Študenti bi bili bolj motivirani za študij, če bi tudi sami krili del stroškov študija. & 2.77 \\
\hline Uvedba šolnin bi povzročila manjšo udeležbo populacije v visokem šolstvu. & 3.27 \\
\hline Z uvedbo šolnin bi se zmanjšale enake možnosti izobraževanja. & 3.37 \\
\hline V primeru uvedbe šolnin bi se vpisovali le tisti, ki imajo resen namen študirati. & 2.55 \\
\hline $\begin{array}{l}\text { Šolnina bi pripomogla k skrajšanju trajanja študija in k večji prehodnosti študen- } \\
\text { tov (manj ponavljanj). }\end{array}$ & 2.69 \\
\hline $\begin{array}{l}\text { Šolnino bi bil-a pripravljen-a odplačevati šele po dokončanem študiju (v obrokih } \\
\text { in v primeru, da bi prejemal-a dovolj visoko plačo). }\end{array}$ & 2.63 \\
\hline $\begin{array}{l}\text { Višina odplačila študentskih posojil bi morala biti povezana z višino plače diplo- } \\
\text { manta. }\end{array}$ & 2.69 \\
\hline $\begin{array}{l}\text { Če bi obstajale šolnine in možnost njihovega odplačevanja preko študentskih } \\
\text { posojil, se za študij ne bi odločil-a zaradi strahu pred bodočim dolgom. }\end{array}$ & 2.48 \\
\hline $\begin{array}{l}\text { Tudi če bi moral-a plačati šolnino, bi se kljub temu šolal-a in po potrebi zadolžil-a, } \\
\text { ker menim, da imam z višjo izobrazbo več možnosti za boljšo in bolje plačano } \\
\text { zaposlitev. }\end{array}$ & 2.93 \\
\hline $\begin{array}{l}\text { Državno podprta posojila bi morala vsebovati spodbude za študente (npr. } \\
\text { zmanjšanje posojilnega dolga, če dokončajo študij v roku). }\end{array}$ & 3.41 \\
\hline $\begin{array}{l}\text { Če bi visokošolske ustanove lahko zaračunale šolnine, bi bolj skrbele za kako- } \\
\text { vost in učinkovitost izvajanja programov. }\end{array}$ & 2.31 \\
\hline $\begin{array}{l}\text { Če bi moral-a plačati šolnino, se ne bi šolal-a, ker menim, da višja stopnja izob- } \\
\text { razbe ne vpliva na višino plače. }\end{array}$ & 1.72 \\
\hline $\begin{array}{l}\text { Glede na to, da je študij brezplačen, se večina šola in študij tudi zaključi, tako da } \\
\text { izobrazba ne prinaša boljših možnosti za zaposlitev. }\end{array}$ & 2.16 \\
\hline
\end{tabular}

Vir: anketa 
Maja Klun, Marina Šućur

Visokošolsko izobraževanje -

njegov pomen in financiranje $v$ Sloveniji

Po letniku študija so se odgovori razlikovali le pri trditvi, glede katere si je bila celotna populacija najmanj enotna. Študenti od 3. letnika naprej (brez absolventov) se ne strinjajo $s$ trditvijo, da se za študij ne bi odločili, če bi morali šolnino $v$ prihodnosti povrniti. Študenti 1. in 2. letnika pa se strinjajo s to trditvijo in se $v$ primeru šolnin zaradi strahu pred bodočim dolgom za študij ne bi odločili.

Odgovore smo obravnavali tudi glede na način študija. Odstopanja od povprečja so se pojavila predvsem pri izrednih študentih. Polovica izrednih študentov (50 odstotkov) meni, da bi si družba in posameznik morala stroške izobraževanja deliti. Ta odstotek ni presenetljiv, saj si izredni študenti sami financirajo študij. Prav tako precej višji delež izrednih študentov (65 odstotkov) namerava študij dokončati v predvidenem času trajanja. Od skupnega povprečja se je njihovo mnenje razlikovalo $v$ strinjanju s trditvijo, da država ni sposobna financirati povečano vključenost prebivalstva $v$ visokošolskem izobraževanju na tradicionalen način. Pričakovano so se tudi, za razliko od skupnega povprečja, strinjali s trditvijo, da je plačilo šolnin za izredni študij v primerjavi z brezplačnim rednim študijem diskriminatorno.

\section{Zaključek}

Šolnine ostajajo »tabu« tema, čeprav ni nujno, da bi v primeru vpeljave šolnin le-te pokrivale celotne stroške izobraževanja. Strokovnjaki namreč zagovarjajo vpeljavo šolnine le $v$ višini 20 do 30 odstotkov stroškov izobraževanja. Velika večina anketirancev se strinja, da bi uvedba šolnin povzročila manjšo udeležbo populacije $\vee$ visokem šolstvu ter da bi se tako zmanjšale enake možnosti izobraževanja. Kljub temu pa se največji delež anketirancev ni strinjal $s$ trditvijo, da se $v$ primeru plačila šolnin ne bi šolali, češ da višja stopnja izobrazbe ne vpliva na višino plače. Torej bi bili vseeno pripravljeni plačati šolnino $v$ pričakovanju bodočih koristi, predvsem denarnih. Nove razmere $v$ visokem šolstvu (množičnost udeležbe, bolonjskih sistem) narekujejo prilagoditev sistema financiranja. Strokovnjaki opozarjajo, da zaradi pomanjkanja sredstev lahko pride do padca kakovosti izvajanja storitev. Kljub temu anketiranci dvomijo, da bi ob povečanju virov, predvsem zasebnih, visokošolske ustanove bolj skrbele za kakovost in učinkovitost izvajanja študijskih programov. 


\section{Maja Klun, Marina Šućur \\ Visokošolsko izobraževanje - njegov pomen in financiranje $v$ Sloveniji}

V luči povečanja udeležbe posameznikov pri financiranju visokošolske izobrazbe bi bilo v Sloveniji smiselno razmisliti o vpeljavi plačila "obresti« za tiste študente, ki študija ne dokončajo $v$ uradno določenem času. Vsaka sprememba povzroča nezadovoljstvo. Potrebni so pogovori in usklajevanja med interesnimi skupinami. Glede na to, da so se študentje najbolj strinjali s trditvijo, da bi državno podprta posojila morala vsebovati spodbude za študente, npr. zmanjšanje posojilnega dolga, če dokončajo študij $v$ roku, lahko sklenemo, da so naklonjeni spodbudam za dokončanje študija $v$ določenem roku. Študij bi bil torej brezplačen za tiste, ki bi svoje študijske obveznosti opravljali pravočasno. S tem bi tudi dosegli večjo prehodnost študentov in manjši osip, saj so tudi rezultati ankete potrdili statistične podatke, da le polovica študentov dokonča študij $v$ roku.

Spremembe na področju visokošolskega izobraževanja so nujne, vsi podatki kažejo na to, da bo tudi sistem financiranja na dolgi rok, kljub zmanjševanju generacij nevzdržen. Po drugi strani tako strokovna javnost kot študenti sami menijo, da je način financiranja nespodbuden za dokončanje študija $\vee$ predvidenem roku. Reformni procesi bodo torej $v$ prihodnosti nujni.

Dr. Maja Klun je docentka na Fakulteti za upravo, Univerze v Ljubljani. Diplomirala, magistrirala in doktorirala je na Ekonomski fakulteti v Ljubljani. Svojo akademsko kariero je kot asistentka pričela leta 1994 z zaposlitvijo na takratni Visoki upravni šoli. Njeno primarno področje raziskovanja in znanstvenega ter strokovnega proučevanja so javne finance, davki, davčni sistem in davčna politika ter institucije in mehanizmi javnega financiranja.

Marina Šućur je diplomirala na Fakulteti za upravo, kjer je zaradi izkazanih nadpovprečnih študijskih dosežkov v študijskih letih 2004/05, 2005/06 in 2007/08 izbrana za najuspešnejšo študentko letnika, $v$ študijskem letu 2008/09 pa je prejela priznanje za najuspešnejšo diplomantko univerzitetnega programa Uprava ter Fakultetno Prešernovo nagrado za diplomsko delo z naslovom Financiranje visokošolskega izobraževanja. Zaposlena je na Univerzi v Ljubljani, v Univerzitetni službi za 1.in 2. stopnjo, kot samostojna svetovalka za skupne programe. 
Maja Klun, Marina Šućur

Visokošolsko izobraževanje -

njegov pomen in financiranje $v$ Sloveniji

\section{Literatura}

- Aghion P., Dewatripont M., Hoxby C., Mas-Colell A. and Sapir A. (2010). The governance and performance of universities: evidence from Europe and the US. Economic Policy, 7-59.

- Bevc M, Stanovnik T., Prevolnik-Rupel V. (2001). Analiza pravičnosti državnega financiranja izobraževanja v Sloveniji in možnosti za njeno povečanje. Ljubljana: Inštitut za ekonomska raziskovanja.

- Bevc, M. (2008). Financiranje, učinkovitost in pravičnost visokega izobraževanja - povezave med temi pojavi in mednarodna konferenca o njih. IB revija, (42), 5-18.

- Del Rey E., Racionero Ma. (2010). Financing schemes for higher education. European Journal of Political Economy, (26), 104-113.

- Eurostat. (2010). Statistics - Education and Training. Retrieved 14. 5. 2010 from Eurostat: http://epp.eurostat.ec.europa.eu/portal/page/portal/education/data/database

- $\quad$ OECD (2009). Highlights from Education at a Glance 2008. Retrieved 20. 9. 2009 from: »http://browse.oecdbookshop.org/oecd/pdfs/browseit/9609011E.PDF«.

- Pravilnik o subvencioniranju bivanja študentov. Uradni list RS, št. 22/2001.

- Pravilnik o subvencioniranju prevozov študentov. Uradni list RS, št. 18/2004.

- Pravilnik o subvencioniranju študentske prehrane. Uradni list RS, št. 70/2007.

- Statistični urad Republike Slovenije (2007). Štipendisti, Slovenija, 2007, začasni podatki. Retrieved 19. 8. 2008 from:

- http://www.stat.si/novica_prikazi.aspx?ID=1789

- SURS 2009, Izobraževanje. Statistične informacije, št. 32. Retrieved 14. 5. 2010 from: http://www.stat.si/doc/statinf/09-SI-200-0901.pdf

- Uredba o javnem financiranju visokošolskih in drugih zavodov, članic univerz, od leta 2004 do leta 2008. Uradni list RS, št. 134/2003.

- Uredba o spremembah in dopolnitvah Uredbe o javnem financiranju visokošolskih in drugih zavodov, članic univerz, od leta 2004 do leta 2008. Uradni list RS, št. 99/2008.

- Vossensteyn, H. (2004). Fiscal Stress: Worldwide Trends In Higher Education Finance. NASFAA Journal of Student Financial Aid, (34)1, Retrieved 10.2.2009 from: "http://www.nasfaa.org/annualpubs/journal/vol34n1/vossensteyn.pdf «.

- Zakon o dohodnini. Uradni list RS, št. 117/2006.

- Zakon o spremembah in dopolnitvah Zakona o štipendiranju. Uradni list, RS št. 40/2009. 
Maja Klun, Marina Šućur

Visokošolsko izobraževanje -

\section{njegov pomen in financiranje v Sloveniji}

- Zakon o spremembah in dopolnitvah Zakona o zdravstvenem varstvu in zdravstvenem zavarovanju. Uradni list RS, št. 76/2008.

- Zakon o starševskem varstvu in družinskih prejemkih (UPB2), Uradni list RS, št. $110 / 2006$.

- Zakon o subvencioniranju študentske prehrane (UPB1). Uradni list RS, št. 74/2007.

- Zakon o štipendiranju. Uradni list RS, št. 59/2007.

- Zakon o visokem šolstvu (UPB3). Uradni list RS, št. 119/2006.

- Zakon o zdravstvenem varstvu in zdravstvenem zavarovanju (UPB3). Uradni list RS, št. 72/2006.

- Zavod Republike Slovenije za zaposlovanje (2010). Letno poročilo 2009. Retrieved 14. 5. 2010 from:

http://www.ess.gov.si/slo/Predstavitev/LetnaPorocila/lp09/LETNO\%20POROCILO\%20Z RSZ\%202009.pdf 